\title{
A Comparative Study on the Spa Sales Model of Uniqlo in the World
}

\author{
Jiayi Wang ${ }^{1, *}$ \\ ${ }^{1}$ Suzhou Experimental High School, Suzhou, Jiangsu 215000, China \\ *Corresponding author. Email:1922592103@qq.com
}

\begin{abstract}
After years of development and using the SPA model, Uniqlo has made great achievements in international operation and has a strong competitiveness in the world. The research topic of this paper is the impact of SPA model on Uniqlo's marketing. This paper analyzes the SPA model of specific marketing methods through collecting the data from Internet. This is a complete supply chain system. It is a one-stop production and sales management mode from raw material procurement, commodity planning, research and development, production to logistics, sales, inventory management and other processes, which is conducive to reducing the cost of supply chain. The SPA mode can better strengthen the control ability of each supply link and supervise the product quality. It can be concluded that the SPA model plays a great role in the marketing of Uniqlo.
\end{abstract}

Keywords: Uniqlo, Spa Sales Model, Comparative study.

\section{INTRODUCTION}

Uniqlo originated in Japan. After years of development, Uniqlo has made great achievements in international markets, and has strong international competitiveness, which has promoted the prosperity and development of the Japanese economy and even world economy. SPA is a professional private label clothing retailer, which has been successfully used and promoted by Uniqlo in Japan. The goal of the Spa model is to meet the needs of the consumer as the primary goal. Effectively connect customers and suppliers through innovative supply methods and supply chain processes to achieve rapid response to the market. The essence of SPA is integration. Uniqlo will participate in the whole process from raw material procurement, product design, product production, logistics, sales, inventory management, store planning and so on. Through the introduction of the SPA business model of Uniqlo, this paper believes that Uniqlo has gained a great market advantage through the SPA business model. By comparing sales data with other similar clothing companies, it can be studied how Uniqlo take advantage of the SPA model to influence its operations and gain greater advantages over other stores. This paper explores how the SPA model has helped Uniqlo achieve its current marketing success, and whether Uniqlo can continue to benefit more from this model in future sales. Based on the above situation, Uniqlo can combine domestic and foreign SPA sales model, strengthen independent research and development and marketing, enhance competitiveness, and take the road of internationalization.

\section{ANALYSIS}

\subsection{Basic Information of Uniqlo}

Uniqlo, founded by Tadashi Yanai, designs, manufactures and retail casual wear. It is the core subsidiary of Japan's Fast Retailing Group, one of the world's leading apparel retailers. With the spread of the global financial crisis, Uniqlo has successfully bucked the trend with its SPA strength and accelerated its global expansion. At the moment, it's growing very quickly. In 2018, Uniqlo's share of the Chinese market reached 25 percent, making China the world's second largest market for the brand. At present, Uniqlo has more than 660 stores in more than 150 cities in China. In 2018, Uniqlo launched its flagship handheld store, offering one-click shopping. Online, users can not only enter through the official website, official APP, WeChat applet, but also through offline scanning code to enter. The handheld 
flagship store integrates multiple online and offline scenarios, so consumers can see the latest news about products in the first time.
Here is the business model canvas below of Uniqlo that directly expresses the core concept of Uniqlo.

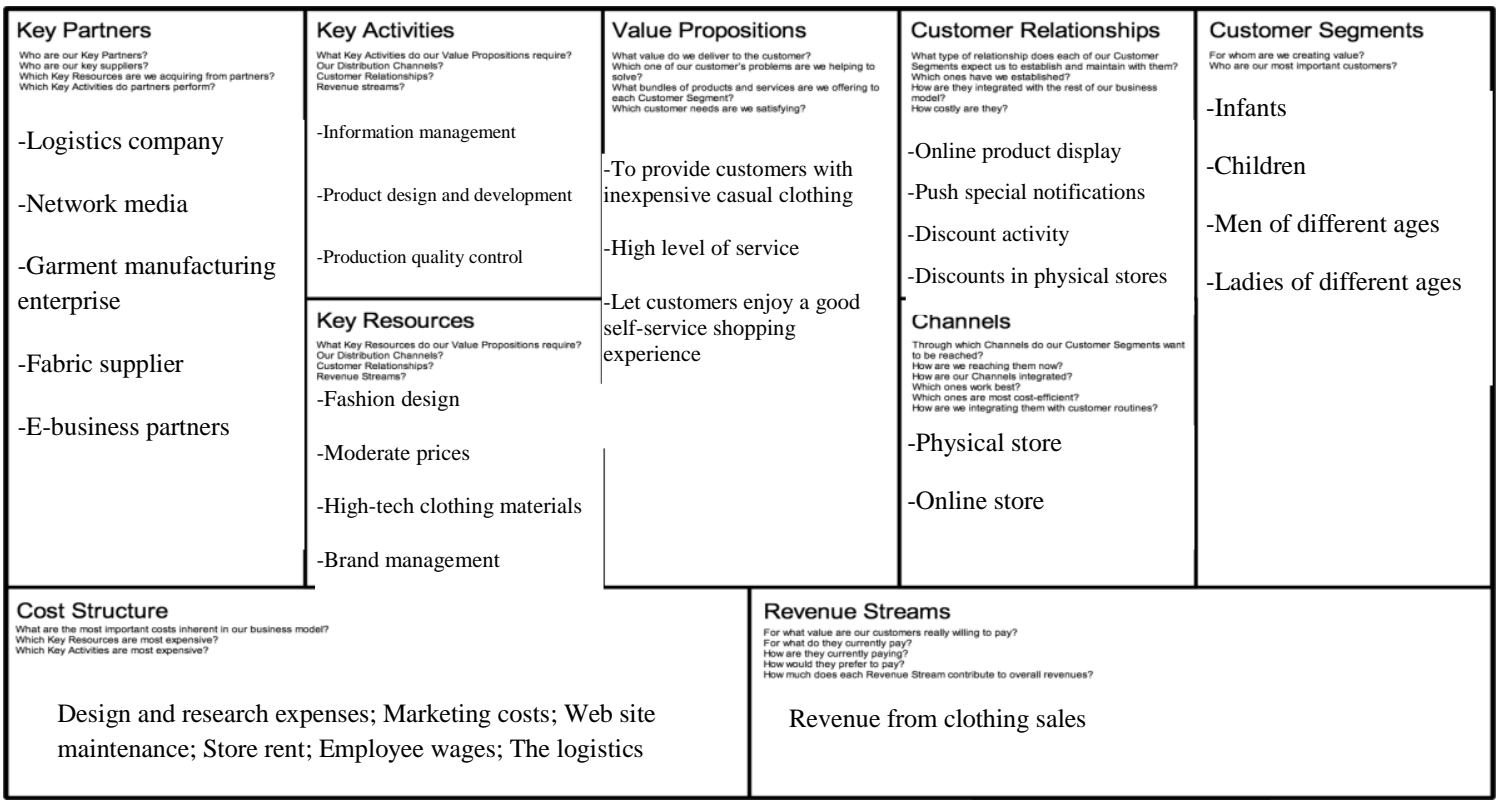

Figure 1 The business model canvas of Uniqlo. (https://wenku.baidu.com/view/e30a44ac182e453610661ed9ad51f01dc28157ea.html)

As for the market positioning of clothing style, Uniqlo has increased the number and novelty of samples while maintaining simplicity. Clothing style can be based on different age levels of consumers and performance more prominent characteristics of the difference. Uniqlo's clothes have various styles and are mainly priced at 300 and 600 RMB. This kind of price strategy enables consumers to choose the clothes they are satisfied with freely in a relaxed and free environment. Within this year, Uniqlo has opened more than 100 stores in China. In a short period of time, the number of Uniqlo stores in the Chinese market expanded by 1.65 times, which means that the corresponding increase in management difficulty is by no means limited to this.

\subsection{Effective SPA Business Model}

The reason why Uniqlo occupies an important position among many clothing brands is because of its excellent SPA sales model that helps Uniqlo a lot, which provides a lot of benefits for Uniqlo. After Uniqlo carried out ABC reform in 1998, the concept of SPA business model gradually took shape. SPA is the business model of a professional retailer with an independent clothing brand. It refers to the one-stop production and sales management mode from raw material procurement, commodity planning, research and development, production to logistics, sales, inventory management and other processes. This is a complete supply chain system. Among them, the production link takes the form of entrustment outsourcing.

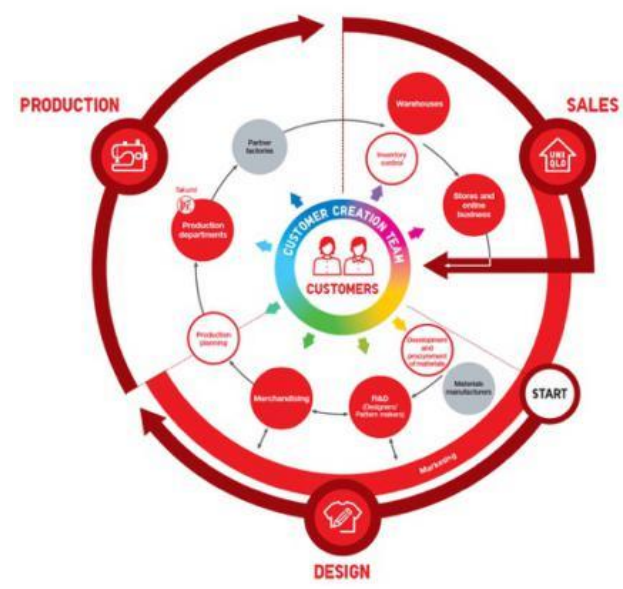

Figure 2 A schematic diagram of Uniqlo SPA mode.

\subsubsection{Planned Steps}

Uniqlo's success in developing unique products by constantly perfecting its SPA model means that Uniqlo's products are iconic and different from other clothing brands. Uniqlo has learned how to adjust production quickly to minimize store operating costs, 
such as entry fees and rent, in order to provide highquality clothing at reasonable prices. Uniqlo's planning process mainly includes research and development and procurement activities to find new materials for its garments. Designers in R\&D meet with representatives from sales, marketing, material development and production departments to discuss and decide on product concepts for the upcoming season. The R\&D center prepares the design according to the product concept and constantly improves the sample until the product is finalized. In terms of procurement, Uniqlo will negotiate directly with the material manufacturers because Uniqlo needs to ensure that the highest quality materials can be obtained at the lowest possible cost. As a consequence, buyers play a vital role from product planning to production. The buyer needs to implement the product concept into the production plan, materials, and design. Merchants will decide the product lineup and output of each season, and formulate detailed marketing strategies. Finally, the buyer decides whether the production will increase or decrease in a season, and inform the planning department to make any adjustment in the production schedule.

\subsubsection{Production Steps}

Uniqlo works with factories on quality control, monitoring and production schedules. To achieve top quality, Uniqlo has several hundred employees in Shanghai, Ho Chi Minh City, Dhaka and Jakarta to form business relationships with partner factories in China, Vietnam, Bangladesh and Indonesia. The production manager will visit the partner's factory every week to get the production department to actively solve the problem. Uniqlo also shares their ideas with the factories they work with to implement radical measures to solve problems.

\subsubsection{Sales Steps}

Uniqlo concentrates on sales and stock because they need to maintain a store inventory. At the end of each season, buyers and marketing also focus on timed sales and limited cycle sales, or launch promotional discounts.

To sum up, Uniqlo has adopted the integrated operation mode of the whole SPA industry chain, which is conducive to reducing the cost of supply chain. At the same time, it can also better strengthen the control ability of each supply link and supervise the product quality. Uniqlo can also get in touch with consumers directly, learn about their preferences and respond quickly. At the same time, Uniqlo can master clear information by itself, such as product quality and delivery date, control the production process by itself, and flexibly respond to the adjustment of orders. The advantage of Uniqlo's SPA mode lies in that the whole process from product design and production to the final sales is under its own control, which some other clothing brands cannot do. In addition, Uniqlo adopts the Point of Sale (POS) sales terminal to manage inventory system, so that it is convenient to know the sales situation of stores in time.

\section{THE INSPIRATION OF UNIQLO SPA BUSINESS MODEL}

First of all, Uniqlo's business model solves the inventory problem very well. If garment enterprises produce a large amount of inventory, it will have a negative impact on business. Uniqlo's business model perfectly avoids such problems. If there is a large inventory, in order to digest the inventory, it will affect the sales of new products. And inventory liquidation often relies on price cuts, which can damage brand image. Uniqlo avoids inventory by controlling the terminal and making accurate forecasts of consumer demand. Because Uniqlo can determine the level of market demand through terminal data analysis.

Uniqlo has a good grasp of the control of sales channels and made predictions. Second, Uniqlo has cultivated the core competitiveness of the enterprise. Let his company in the clothing industry to become a strong competitor. The SPA business model can help Uniqlo enter the upstream raw material research and development of the garment industry and the downstream brand marketing and other core links of the value chain.

In contrast, many domestic garment enterprises advocate the asset-light model, which can indeed increase corporate profits in the short term. However, this will make the company lack of the cultivation of core competitiveness, and unable to make the enterprise to maintain sustainable growth.

\section{SUGGESTION}

However, Uniqlo still has some minor problems. Initially Uniqlo's clothing prices were too low, a strategy that threatened to cause prices to collapse. Because Uniqlo aims to make clothes that are appropriate for people of different gender ages, its designs often lack individuality, a fact that has built a reputation for what many see as the company's 
weakness. However, Uniqlo quickly improved its marketing approach and decided to actively work with well-known designers to achieve diversity and excellence in design. In this way, Uniqlo gained the commercial foundation for its success, allowing for further innovation in the design and functionality of its products. Later, with the establishment of the SPA model, as well as the expansion in design and functionality, Uniqlo moved from the domestic market to the international market. The company is expanding its business worldwide. The growth has been particularly marked in Asian countries. Asia accounts for about $70 \%$ of the company's overseas sales. In addition, the company is working to further enhance its global brand image.

Here are some of our suggestions for Uniqlo's current development:

First, at the product level. As Uniqlo focuses on basic leisure, the clothes still lack a sense of fashion. Because nowadays people prefer stylish clothes, so it is necessary to research and develop some clothes that keep up with the trend. This can attract more customers and increase the purchase volume.

Secondly, in terms of marketing, Uniqlo can improve its marketing system by conducting some research and analysis, and at the same time try new methods of brand promotion. Because the times are changing faster and faster, it is very important to meet the needs of consumers.

Finally, in terms of marketing, although Uniqlo implements a completely open shopping choice model, this model cannot be well adapted to the changes of consumer groups. For example, Uniqlo can choose to provide some consumption guidance. It can display the effect of simulating try-on of products through technology, set up a rest area in the physical store, and provide some fashion magazines.

\section{CONCLUSION}

To sum up, above, this paper discussed the development status of Uniqlo and its SPA marketing strategy. It can be found that Uniqlo has done a good job in every aspect of its marketing through the detailed planning of the SPA model. Through this competitive marketing model, Uniqlo has gradually grown into a world-class clothing brand. However, there are still some shortcomings in this paper. Due to the epidemic, the information and data can only be obtained through some secondary surveys and some basic information on the Internet and summarize the SPA sales model of Uniqlo. In the follow-up research, some investigations by ourselves, personally ask consumers' feelings and interview some employees of Uniqlo to deeply explore the effect of SPA sales mode on marketing can be conducted.

\section{AUTHORS' CONTRIBUTIONS}

This paper is independently completed by Jiayi Wang.

\section{ACKNOWLEDGMENTS}

I am very grateful to my professors and teaching assistants for the successful completion of this 3,000word paper. Every teacher is very concerned about me, asking me about my progress, answering my questions enthusiastically, and actively helping me solve my troubles. At the same time, they also gave us some small tasks to promote the idea of this paper, which enlighten me a lot.

\section{REFERENCES}

[1] FAST RETAILING. UNIQLO Business Model. 2021.02.26: 1

[2] mintywebs. 14 Ways to Apply the Business Model Canvas. Apr 8, 2016: 1

[3] HongLi Ma. Research on Uniqlo's International Management.

[4] Fast Retailing. Uniqlo. 2012: 31-34, 40-44

[5] Eriko Kinashi. UNIQLO: Strategy toward the World-Leading Apparel Company. Nov 16, 2011: 1

[6] Qianmingyu Zhou. Market Watch (2019) analyzes Uniqlo's brand strategy, existing problems and corresponding development countermeasures. 2019

[7] Hunan College of Commerce. Uniqlo Analytics (2019). 2019: 2, 5-7

[8] Uniqlo Business Model Analysis. 2020: 2-3, 6 